\title{
CARDIAC FUNCTION OF BASKETBALL PLAYERS UNDER STRESS TRAINING
}

\author{
FUNÇÃO CARDÍACA DE JOGADORES DE BASQUETEBOL NO TREINAMENTO DE ESTRESSE \\ FUNCIÓN CARDÍACA DE JUGADORES DE BALONCESTO EN EL ENTRENAMIENTO DE ESFUERZO
}

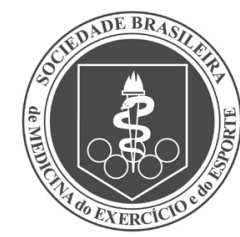

Original Article

ARTIGO ORIGINAL

Artículo Original
Keyin Liu' (D)

(Physical Education Professional)

1. Civil Aviation Flight University of China, Sports Department,

Guanghan, Sichuan, China.

\section{Correspondence:}

Keyin Liu

Guanghan, Sichuan, 618307, China.

liukeyin36@163.com

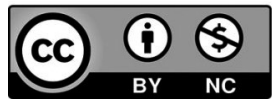

\begin{abstract}
Introduction: Basketball can enhance the physical fitness of young people, promote the growth and development of their bodies, and improve health and athletic ability. Objective: To explore the characteristics of basketball players' cardiac response to increasing load training. Methods: By analyzing 12 juvenile male amateur basketball training athletes, when performing incremental load exercises on the treadmill, using a 12-lead electrocardiograph to record the electrocardiogram, $H R$, and blood pressure responses for each level of exercise. Results: The mean heart rate of the basketball players before movement was $82.45 \pm 11.44 \mathrm{bpm}$, slightly higher than the heart rate at rest. Depending on the exercise load, the blood pressure should increase by 5 to $12 \mathrm{mmHg}$. Under different load training conditions, each level of blood pressure in the Bruce treadmill test procedure should increase $12.5 \sim 44 \mathrm{mmHg}$. The basketball player's systolic pressure increased by $2.25 \sim$ $15.7 \mathrm{mmHg}$, diastolic pressure increased by 0.43 to $11.37 \mathrm{mmHg}$. Conclusions: In basketball players, the psychological stress is less than that of the average person performing the same exercise. The strong ability to adapt to exercise under incremental load training, the contractility of the ventricular muscles and the development of the heart are good. Level of evidence II; Therapeutic studies - investigation of treatment results.
\end{abstract}

Keywords: Training; Cardiovascular; Basketball.

\section{RESUMO}

Introdução: O basquete pode melhorar a aptidão física dos jovens, promover o crescimento e o desenvolvimento corporal e melhorar a saúde e a capacidade atlética. Objetivo: Explorar as características da resposta cardíaca de jogadores de basquete ao aumento da carga de treinamento. Métodos: Analisar 12 atletas juvenis em treinamento de basquete amador masculino durante exercícios de carga incremental em esteira por meio de eletrocardiógrafo de 12 derivações para registrar as respostas elétricas do coração, a FC e a pressão arterial em cada nivel de exercício. Resultados: A frequência cardíaca média dos jogadores de basquete antes do exercício foi de 82,45 \pm 11,44 bpm, ligeiramente superior à frequência cardíaca em repouso. Dependendo da carga de exercício, a pressão arterial deve aumentar de 5 a $12 \mathrm{mmHg}$. Em diferentes condições de treinamento de carga, cada nível de pressão arterial no teste em esteira Bruce deve aumentar 12,5 44 mmHg. A pressão sistólica dos jogadores de basquete aumentou 2,25 $15,7 \mathrm{mmHg}$, a pressão diastólica aumentou 0,43 para $11,37 \mathrm{mmHg}$. Conclusões: Nos jogadores de basquete, o estresse psicológico é menor do que a dos não atletas que realizam o mesmo exercício. A grande capacidade de adaptação ao exercício com treinamento de carga incremental, a contratilidade dos músculos ventriculares e o desenvolvimento do coração são bons. Nível de Evidência ll; Estudos terapêuticos - Investigação dos resultados do tratamento.

Descritores: Treinamento; Cardiovascular; Basquetebol.

\section{RESUMEN}

Introducción: El baloncesto puede mejorar el acondicionamiento fisico de los jóvenes, promover el crecimiento y el desarrollo corporaly mejorar la salud y la capacidad atlética. Objetivo: Explorar las características de la respuesta cardíaca de los jugadores de baloncesto al aumento de la carga de entrenamiento. Métodos: Analizar a 12 atletas juveniles de baloncesto amateur en entrenamiento durante ejercicios de carga incremental en caminadora utilizando un electrocardiógrafo de 12 derivaciones para registrar las respuestas eléctricas del corazón, la FCy la presión arterial en cada nivel de ejercicio. Resultados: La frecuencia cardíaca media de los jugadores de baloncesto antes del ejercicio fue de 82,45 $\pm 11,44$ lpm, ligeramente superior a la frecuencia cardíaca en reposo. Dependiendo de la carga de ejercicio, la presión arterial debe aumentar entre 5 y $12 \mathrm{mmHg}$. Bajo diferentes condiciones de entrenamiento de carga, cada nivel de presión arterial en la prueba de Bruce debe aumentar en 12,5 44 mmHg. La presión sistólica de los jugadores de baloncesto aumentó de 2,25 a 15,7 mmHg, la presión diastólica aumentó de 0,43 a 11,37 mm Hg. Conclusiones: En los jugadores de baloncesto, el estrés psicológico es menor que el de los no deportistas que realizan el mismo ejercicio. La gran capacidad de adaptación al ejercicio con entrenamiento de carga incremental, la contractilidad de los músculos ventriculares y el desarrollo del corazón son buenos. Nivel de Evidencia ll; Estudios terapéuticos - Investigación de los resultados del tratamiento.

Descriptores: Entrenamiento; Cardiovascular; Baloncesto. 


\section{INTRODUCTION}

Basketball is a comprehensive sport that combines aerobic exercise and anaerobic exercise, is a long time, high-intensity sports, mainly aerobic metabolism, supplemented by anaerobic metabolism, good aerobic and anaerobic metabolic capacity is a solid foundation for athletes to win in the competition. 'The total distance that an excellent basketball player can move in a competitive game can reach 2452.2 meters, in the total moving distance, fast running accounts for about 398 meters, running at medium speed occupies about 472 meters, slow running takes about 464 meters, it takes about 539 meters to walk, and about 580 meters to slide, jump about 39 times, the time when the heart rate is between 168-180 beats/ $\min$ is $40.8 \%$ of the total time, the time when the heart rate is $140-180$ beats/min is $46.6 \%$ of the total competition time, the time when the heart rate is lower than 140 beats/min is only $12.6 \%$ of the total competition time. ${ }^{2-3}$ Basketball is mainly composed of quick and sudden movements, when a basketball player completes a quick attack, most forwards and defenders are the main players, in each game, the quick attack score can reach 30-40 points, the number of fast breaks in the game can reach 1520 times, this type of rapid conversion of offense and defense is mainly powered by anaerobic metabolism 19.201. ${ }^{4}$ Basketball requires athletes to have the ability to move quickly, transfer to the corresponding location within the specified time, in order to make better use of technology and achieve certain tactical goals. The interconnection of each link needs to have a certain speed, the links are tightly connected, there is no intermittent time in the process of offensive and defensive conversion, there are higher requirements for athletes'speed and endurance..$^{5-6}$ During the rapid completion of the offensive and defensive transition, the athletes make a series of actions such as sudden start, dribbling, variable speed running, shooting, layup, and rebounding, to complete the above actions requires good speed endurance as support, ensure that athletes maintain a stable performance of skills and tactics in the continuous round-trip offensive and defensive transitions. ${ }^{7}$ Aerobic exercise capacity and anaerobic exercise capacity complement each other, good aerobic exercise capacity is the basis for athletes to perform steadily in competitions. Based on the current research, Nau C et al. proposed that, the cardiopulmonary function indicators are divided into three categories that reflect exercise endurance, strength, and heart function indicators: Anaerobic threshold, kilogram oxygen consumption, oxygen metabolic equivalent, maximum oxygen pulse, respiratory quotient, gas exchange rate and maximum oxygen consumption, etc.; Response ventilatory function indicators: Respiratory reserve, maximum ventilation, maximum respiratory rate, maximum tidal volume, etc.; Reaction gas exchange index: Carbon dioxide equivalent, oxygen equivalent, tidal volume, etc. ${ }^{8}$

\section{METHOD}

\section{Experimental subjects}

Twelve male juvenile athletes trained in amateur basketball in a certain city, the training time was $(3.67 \pm 1.94)$ years. The general physical condition of the subject: Age (14.78 \pm 0.44$)$ years old, height (184.45 \pm $7.54) \mathrm{cm}$, weight $(68.0 \pm 7.45) \mathrm{kg}$, Quetelet index (368.91 \pm 38.58$)$, heart rate before exercise $(82.45 \pm 11.44)$ beats/min, pre-exercise systolic blood pressure $(129.38 \pm 20.18) \mathrm{mmHg}(1 \mathrm{mmHg}=0.133 \mathrm{kPa})$, diastolic blood pressure before exercise $(80.0 \pm 20.18) \mathrm{mmHg}$, peak heart rate $(199.43 \pm 34.29)$ beats/min.

\section{Method}

Place the 12-lead ECG electrode before the treadmill exercise test: Place the breathing mouth and nose clip, and to ensure that there is no air leakage. Treadmill test: Run the treadmill test immediately after $1 \mathrm{~min}$ of warm-up activities on the American-made SensorMedicsTreadmill2000 on the treadmill. The speed and slope of the treadmill test are shown in Table 1 using the Bruce scheme. Each level of exercise is 3 minutes, no gaps are automatically upgraded, exercise to exhaustion.

When the subject is doing incremental load exercise on the treadmill, a 12-lead electrocardiograph was used to record the electrocardiogram, keartrate, HR and blood pressure response of each level of exercise.

\section{RESULTS}

\section{Body shape}

1. The average height of the basketball players measured is $184.45 \mathrm{~cm}$, it is $16.89 \mathrm{~cm}$ and $15.37 \mathrm{~cm}$ higher than the average height of 15-year-old boys in Chinese cities and $169.08 \mathrm{~cm}$, respectively.

2. The average weight of the basketball players measured is $68.0 \mathrm{~kg}$, it is $13.89 \mathrm{~kg}$ and $11.91 \mathrm{~kg}$ higher than the average weight of 15 -year-old boys in Chinese cities, $54.11 \mathrm{~kg}$ and $56.09 \mathrm{~kg}$, respectively.

3. Quetelet index represents the weight per centimeter of height, reflects the fullness of the human body, that is, as the relative weight to reflect the body's circumference, width, thickness and body tissue density. The basket player Quetelet index is 368.91, it is 45.98 and 37.17 higher than the Quetelet index of 15-year-old boys in Chinese cities of 322.93 and 331.74 of 15-year-old boys in a certain city respectively. From the measurement results of the above indicators, it can be seen that the height, weight and Ketuo Cai index are significantly higher than boys of the same age in the country and a province, this is closely related to genetics, nutrition, and physical exercise. It reflects the good bone growth, muscle development and body fullness of the basketball players. ${ }^{9}$

\section{Heart rate response}

When exercising in different training states, as the exercise intensity increases, in order to meet the needs of the body's metabolism, the heart rate rises linearly within a certain range, for every $1 \mathrm{MET}$ increase in exercise load, the heart rate should increase by 5 to 10 beats $/ \mathrm{min}$. The average resting heart rate of boys between 14 and 15 years old in China is 80.1 beats/min. This function does not measure the heart rate at rest. The heart rate before exercise is usually higher than the heart rate at rest, which is a natural conditioned reflex, it is the pre-exercise stress state, also called the pre-match state. As shown in Figure 1, the heart rate of the basketball player before exercise is $82.45 \pm 11.44 \mathrm{~b} / \mathrm{min}$, which is slightly higher than the heart rate at rest. This reflects that basketball players have less psychological stress on the same sport than ordinary people.

Table 2. Sports Bruce treadmill test plan under different training conditions.

\begin{tabular}{c|c|c|c|c|c|c|c}
\hline \multirow{2}{*}{ Project } & \multicolumn{7}{|c}{ Level } \\
\cline { 2 - 8 } & $\mathbf{1}$ & $\mathbf{2}$ & $\mathbf{3}$ & $\mathbf{4}$ & $\mathbf{5}$ & $\mathbf{6}$ & $\mathbf{7}$ \\
\hline Speed & 2.7 & 4.0 & 5.4 & 6.7 & 8.0 & 8.8 & 9.6 \\
\hline Slope & 10 & 12 & 14 & 16 & 18 & 20 & 22 \\
\hline $\begin{array}{c}\text { Exercise } \\
\text { equivalent }\end{array}$ & 4.6 & 7.1 & 10.2 & 13.5 & 17.2 & 20.4 & 23.8 \\
\hline
\end{tabular}

Table 1. Basic situation.

\begin{tabular}{c|c|c|c|c|c|c|c}
\hline Age & Height & Weight & Quetelet Index & $\begin{array}{c}\text { Heart rate before } \\
\text { exercise }\end{array}$ & $\begin{array}{c}\text { Systolic blood } \\
\text { pressure before } \\
\text { exercise }\end{array}$ & $\begin{array}{c}\text { Pre-exercise } \\
\text { diastolic blood } \\
\text { pressure }\end{array}$ & $\begin{array}{c}\text { Peak heart rate } \\
\text { perces }\end{array}$ \\
\hline $14.78 \pm 0.44$ & $184.45 \pm 7.54$ & $68.0 \pm 7.45$ & $368.91 \pm 38.58$ & $82.45 \pm 11.44$ & $129.38 \pm 20.18$ & $80.0 \pm 20.18$ & $199.43 \pm 34.29$ \\
\hline
\end{tabular}




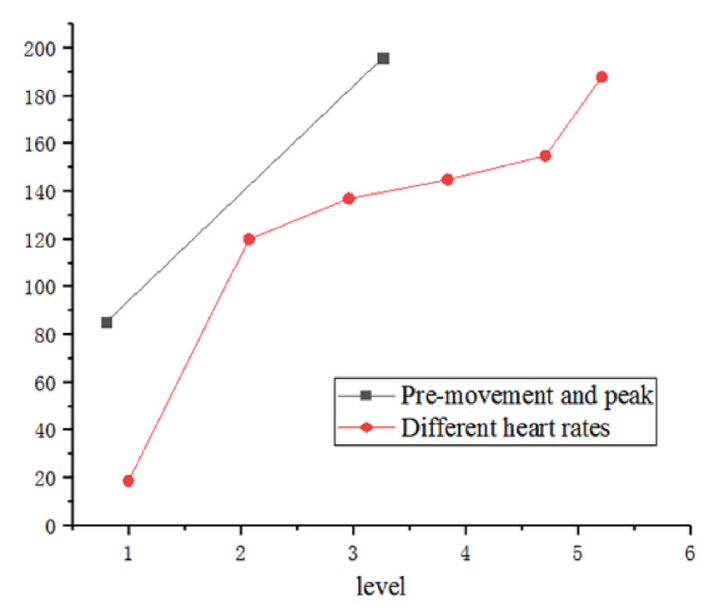

Figure 1. Basketball players' heart rate response to exercise under different training conditions.

\section{Blood pressure response}

Blood pressure is a commonly used index to assess the amount of exercise and training level, the systolic blood pressure mainly reflects the contractility of the ventricular muscles and the output blood volume: Diastolic blood pressure mainly reflects peripheral resistance and arterial elasticity. The normal blood pressure of Chinese adolescents is 100 130/60 80 mmHg. Blood pressure 112.23/66mmHg of 15-year-old urban boys in China: This function monitor does not measure the blood pressure at rest. According to the pre-exercise heart rate, the pre-exercise blood pressure of the basketball players is $129.38 / 80 \mathrm{mmHg}$ higher than the blood pressure at rest, and they are in a pre-exercise stress state. As shown in Figure 2, during exercise in different training states, the systolic blood pressure and diastolic blood pressure of basketball players at all levels increased linearly, and did not rise much, and there was no fluctuation. According to each increase of 1 MET of exercise load, blood pressure should increase by $5 \sim 12 \mathrm{mmHg}$, under different training conditions, the blood pressure of each level of exercise Bruce treadmill test program should increase by $12.5 \sim 44.4 \mathrm{mmHg}$, the systolic blood pressure of basketball players at all levels increased by $2.25 \sim 15.7 \mathrm{mmHg}$, diastolic blood pressure increased by $0.43 \sim 11.37 \mathrm{mmHg}$. It reflects that the basketball players have strong adaptability to different training conditions, the contractility of the ventricular muscles and the development of the heart are good.

\section{DISCUSSION}

The height, weight and body fullness of basketball players are better than those of ordinary teenagers of the same age, and their bodies grow well. In one case, the degree of body fullness was small, lower than that of the average teenager of the same age, and the thoracic development was abnormal, and the shape was chicken breast. It is recommended to strengthen medical supervision and pay close attention to the cardiopulmonary function response during high-intensity and high-volume training. The heart rate response of exercise in different training states, the heart rate of all levels of exercise rises linearly, and the increase is not large, the cardiovascular system adapts well to incremental exercise. In the state of increasing load training, the systolic and diastolic blood pressures of all levels of exercise increased steadily, the increase is within the normal range.

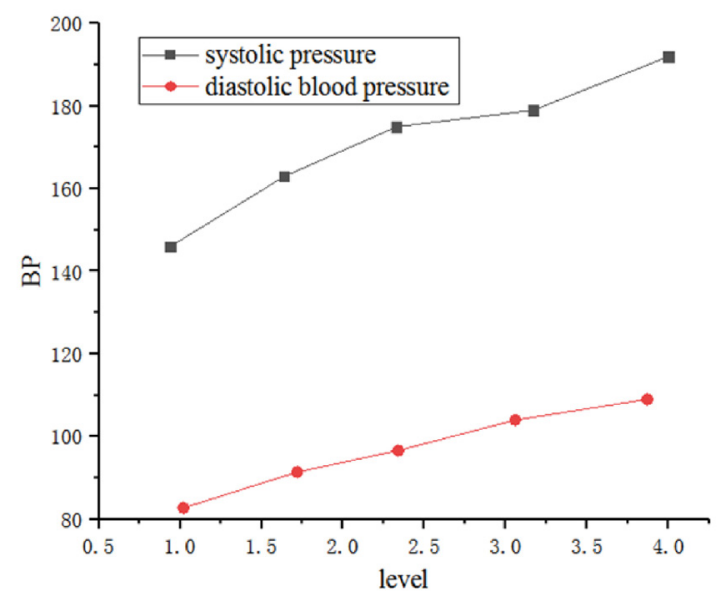

Figure 2. Basketball players' blood pressure response to exercise under different training conditions.

The heart system is well developed..$^{10}$ For athletes, special technical movements and tactical coordination exercises are the focus of training, however, physical training cannot be ignored, the execution of skills and tactics depends on the support of good physical fitness. Through physical function training, heart rate reserve can be increased, and physical function status can be improved, improving athletes' competitive level will help athletes obtain good athletic performance. Physical function training includes two contents: ability improvement and physical therapy. Physical motor function training pays more attention to details, can fundamentally discover and improve athletes' problems, reduce the occurrence of sports injuries. Sports training is a complicated and boring job, and it is a severe challenge to the athlete's will and quality. Body motor function training not only pursues physical exercises, it also pays attention to psychological counseling and encouragement to help athletes devote themselves to training with full enthusiasm.

\section{CONCLUSION}

In the process of competitive sports, use scientific methods to conduct physiological and biochemical tests on athletes, to understand and master the physiological functions of athletes in time, accurately evaluate the improvement of sports ability, scientifically adjust the method of sports training, promote the improvement of athletes' physical fitness, it plays a good role in the stable performance of athletes'skills and tactics in competitive competitions. Exploring the characteristics of basketball players' heart response based on incremental load training, the heart rate of the basketball player before exercise is $82.4511 .44 \mathrm{~b} / \mathrm{min}$, slightly higher than the heart rate at rest. This reflects the basketball players, the psychological stress to the same exercise is less than that of the average person. In the state of incremental load training, the blood pressure of each level of the Bruce treadmill test program should increase by $12.5 \sim 44.4 \mathrm{mmHg}$, the systolic blood pressure of basketball players at all levels increased by $2.25 \sim 15.7 \mathrm{mmHg}$, diastolic blood pressure increased by $0.43 \sim 11.37 \mathrm{mmHg}$. Both systolic blood pressure and diastolic blood pressure rose steadily, within the normal range, and the heart system developed well.

The author declare no potential conflict of interest related to this article 


\section{REFERENCES}

1. Christopher T, Irene K, Thomas D, Jones PA. Differences in Vertical Jump Force-Time Characteristics between Stronger and Weaker Adolescent Basketball Players. Sports. 2017;5(3):63.

2. Urea-Bonilla P, Blanco-Romero L, Sánchez-Urea B, Salas-Cabrera J. Psychological characteristics and self-assessment of performance in costa rican soccer and basketball players of the first division. Cuad Psicol Deporte. 2015;15(2):13-20.

3. Sperlich PF, Behringer $M$, Mester J. The effects of resistance training interventions on vertical jump performance in basketball players: a meta-analysis. J Sports Med Phys Fitness. 2016;56(7-8):874-83.

4. Xu DS, She C, Wang J, Cui JJ, Cai H, Bai WZ. Characteristics of Distribution of Blood Vessels and Nerve Fibers in the Skin Tissues of Acupoint "Taichong" (LR 3) in the Rat. Acupunct Res. 2016;41 (6):486-91.

5. Fischer L, Rienhoff R, Tirp J, Baker J, Strauss B, Schorer J. Retention of Quiet Eye in Older Skilled Basketball Players. J Mot Behav. 2015;47(5):1-8.
6. Nau C, Seebach C, Trumm A, Schaible A, Kontradowitz K, Meier S, et al. Alteration of Masquelet's induced membrane characteristics by different kinds of antibiotic enriched bone cement in a critical size defect model in the rat's femur. Injury. 2016;47(2):325-34.

7. Tochitani T, Mori M, Matsuda K, Kouchi M, Fujii Y, Matsumoto I. Histopathological characteristics of renal changes in human renin-angiotensinogen double transgenic rats. J Toxicol Pathol. 2016;29(2):125-9.

8. Kostadinova-Petrova I, Mitevska E, Janeska B. Histological Characteristics of Bruises with Different Age. Open Access Maced J Med Sci. 2017;5(7):813-7.

9. LeeW, Ryou HS, Kim S, Nam JW, LeeWS, Cho SW. Study of hemodynamic parameters to predict coronary artery disease using assumed healthy arterial models. J Mech Sci Technol. 2015;29(3):1319-25.

10. Kilding AE, Dobson BP, Ikeda E. Effects of Acutely Intermittent Hypoxic Exposure on Running Economy and Physical Performance in Basketball Players. J Strength Cond Res. 2015;30(7):2033. 